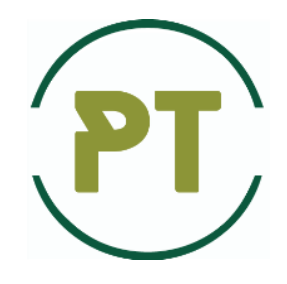

Problems of Tribology, V. 25, No 1/95-2020, 6-15

\title{
Problems of Tribology
}

Website: http://tribology.khnu.km.ua/index.php/ProbTrib

E-mail: tribosenator@gmail.com

DOI: https://doi.org/10.31891/2079-1372-2020-95-1-6-15

\section{Wear resistance and physicochemical properties of $12 \mathrm{XH3A}$ carbohydrated steel}

\author{
M.Ye. Skyba ${ }^{1}$, M.S. Stechyshyn ${ }^{1}$, M.M. Luk'yanyuk ${ }^{1}$, A.V. Martynyuk ${ }^{1 *}$, \\ M.I. Tsepenyuk ${ }^{2},{ }^{3}$ V.A. Gerasimenko \\ ${ }^{I}$ Khmelnitskyi National University, Ukraine \\ ${ }^{2}$ Ternopil National Technical University. I. Pulya \\ ${ }^{3}$ Sumy National Agrarian University \\ *E-mail:av.mart@ukr.net
}

\section{Abstract}

The results of the study of anhydrous carbohydrogenation influence in a smoldering discharge on the microhardness of a hardened 12XH3A steel layer depending on the propane content and pressure of the gas environment are presented in the paper. In accordance with the developed methodology of studying the influence of technological parameters of the process of carbonylation on the properties of structural materials, optimal modes of hardening of 12XH3A steel, depending on the operating conditions have been found.

Key words: carbohydration, microhardness, structure.

\section{Introduction}

Carbohydration in glow discharge is the process of saturation of the metal surface with nitrogen and carbon at low temperatures (from $500{ }^{\circ} \mathrm{C}$ to $600{ }^{\circ} \mathrm{C}$ ). The results of studies of this process are presented in [1, 2]. In these works, the simultaneous saturation of metal with carbon and nitrogen was not considered as an independent method of surface hardening, but the effect of carbon on the structure and properties of nitrided layers during quenching in ammonia plasma with the addition of carbon containing gases was investigated.

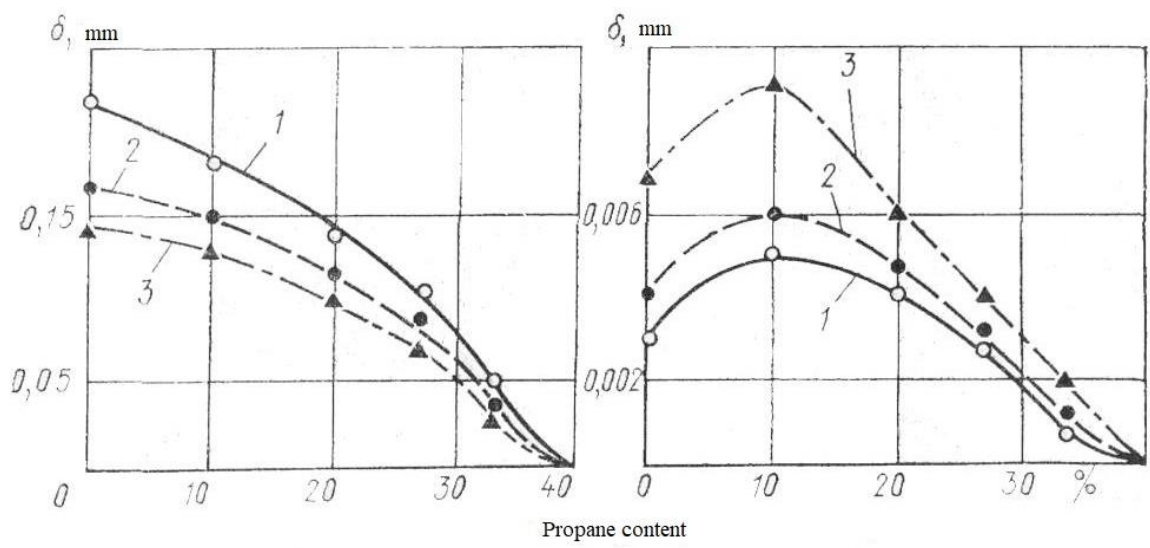

Fig. 1. Effect of the concentration of propane in the gas mixture at BATR on the depth of the diffusion layer (a) and carbonitrid zone (b):

$$
\begin{gathered}
\text { 1 - technical iron; } \\
\text { 2-steel 40X; } \\
\text { 3-38NMUA steel [1] }
\end{gathered}
$$


So, without hydrogen nitriding in a glow discharge (BATR) with propane additives, a layer with a developed carbonitride surface zone is formed, which is contained in the zone of internal nitriding carbonitride mesh along the boundaries of austenitic grains. The introduction of propane into ammonia plasma decreases the rate of formation of the internal nitriding zone (Fig. 1).

The dependence of the thickness of the carbonitride zone [Fe2-3 (NC)] on the concentration of cementitious gas, such as propane, is of extreme nature. The maximum development of the carbonitride zone is obtained with a propane content in the mixture of $8 \%$ to $12 \%$. In this case, its thickness is 1.5 times greater than the depth of the nitride zone, which is obtained by nitration in ammonia plasma. With a propane content of about 40 $\%$, the growth of the nitrided layer is suppressed, apparently due to the formation of a carbonitride or carbographic film on the surface.

Also, the effect of the composition of the saturating atmosphere on the wear resistance of 38HMUA steel has been studied (Fig. 2).
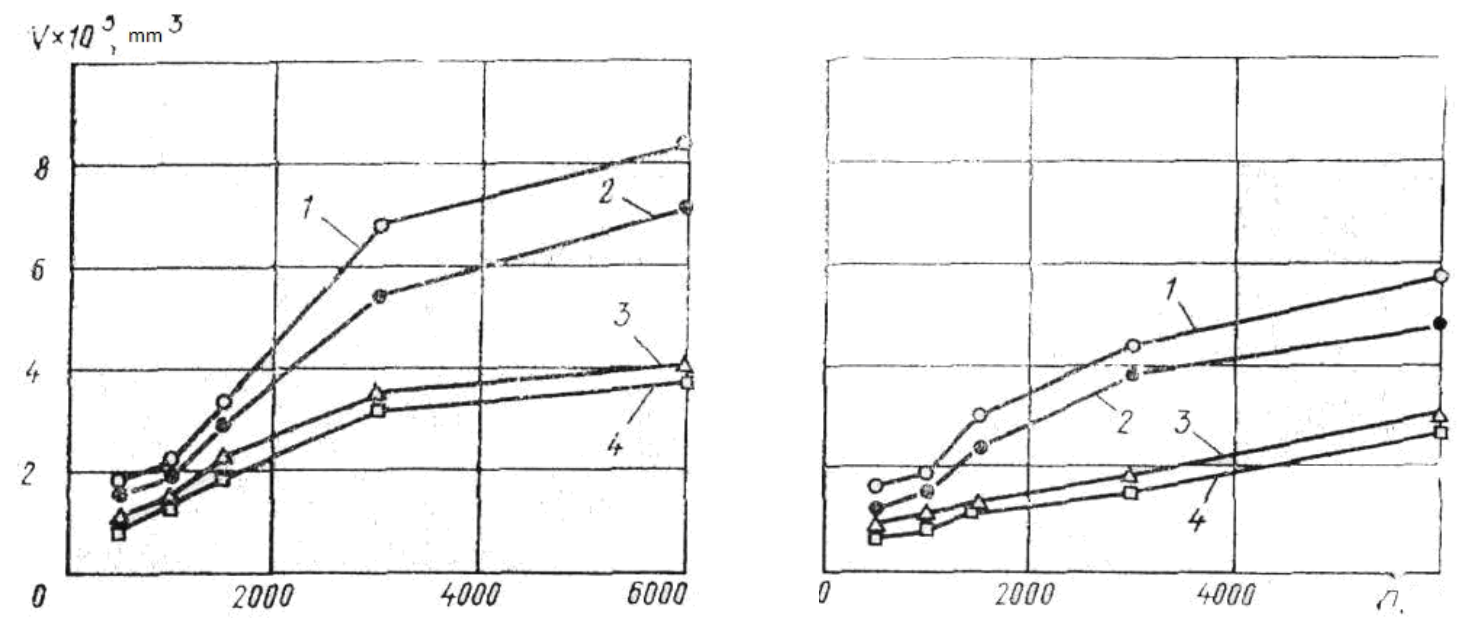

Fig. 2. The influence of the composition of the medium on the wear resistance of steel $38 \mathrm{HMUA}$, nitrided at a temperature of $520^{\circ} \mathrm{C}(\mathrm{a})$ and $650{ }^{\circ} \mathrm{C}(\mathrm{b})$ : $1-100 \% \mathrm{NH}_{3}$;

$2-10 \% \mathrm{NH}_{3}+90 \% \mathrm{Ar}$

$3-90 \% \mathrm{NH}_{3}+10 \% \mathrm{C}_{3} \mathrm{H}_{8}$

$4-1,5 \mathrm{~h}\left(10 \% \mathrm{NH}_{3}+90 \% \mathrm{Ar}\right)+1,5 \mathrm{~h}\left(90 \% \mathrm{NH}_{3}+10 \% \mathrm{C}_{3} \mathrm{H}_{8}\right)[16]$

The wear resistance of steel nitrided at $520{ }^{\circ} \mathrm{C}$ and $650{ }^{\circ} \mathrm{C}$ has been investigated for $1.3 \mathrm{~h}$ in ammonia and in mixtures of ammonia with propane and argon. In addition, combined processes have been performed according to a two-stage scheme: in the first stage $(1.5 \mathrm{~h})$, an internal nitriding zone was formed on the surface of the steel during treatment in ammonia-argon (10\% ammonia $+90 \%$ argon) plasma, and in the second stage (1, $5 \mathrm{~h}$ ) a carbonitride zone was formed based on the $\varepsilon-\mathrm{Fe} 2-3$ carbonitride (NC). As it can be seen from the graphs, the introduction into the ammonia of propane plasma, allows to further increase the wear resistance of the nitrated surface (curve 3 ) due to the formation of carbonitride $\varepsilon$-phase.

An additional reserve of increasing the properties of surface layers of nitrided steels is the use of combined processes: Stage I - the formation of the zone of internal nitriding by the mode of cathodic atomization in argon plasma (from $85 \%$ to $95 \%$ ) and ammonia (from $5 \%$ to $15 \%$ ); Stage II - guidance on the surface of the diffusion layer of carbonitride zone in plasma of ammonia $(90 \%)$ and propane $(10 \%)$ at optimum pressure. Such modes allow to intensify saturation and provide maximum wear resistance (curve 4, Fig. 2.)

The technological parameters of the carbon dioxide process in the glow discharge significantly influence the physical and mechanical characteristics, structure, phase composition and wear resistance of the carbonitride layer, so studying this effect is an important task.

The purpose of the research is to determine the dependence of the characteristics of the carbohydrate layer (depth, hardness, structure, phase and chemical composition) and their wear resistance on the basic parameters of the technological process (pressure, composition of the saturation medium, temperature and duration of the process).

\section{Research methodology}

Studies of the process of carbon dioxide in the glow discharge have been carried out at the experimental unit UATR - 1, which provides the strengthening of both samples and industrial parts with a diameter of up to $400 \mathrm{~mm}$ and a length of up to $1000 \mathrm{~mm}$.

The studies have been carried out on steel 12XH3A. The mixtures of nitrogen and argon $(75 \% \mathrm{~N} 2+25 \% \mathrm{Ar})$ and $\mathrm{C}_{3} \mathrm{H}_{8}$ propane were used as the working gases, the saturation temperature varied from $480{ }^{\circ} \mathrm{C}$ to $600{ }^{\circ} \mathrm{C}$, the 
pressure of the gas mixture during the diffusion saturation process - from $80 \mathrm{~Pa}$ to $400 \mathrm{~Pa}$, the duration of the process - 20 minutes to 240 minutes.

Studies have been performed on the installation of face friction [3].

The test sample has been measured at 15 points, after which the average height of the sample has been determined. The difference in height of the sample before and after the study is the linear amount of wear.

The design of the sample and the counterpart to it is shown in Fig. 3.
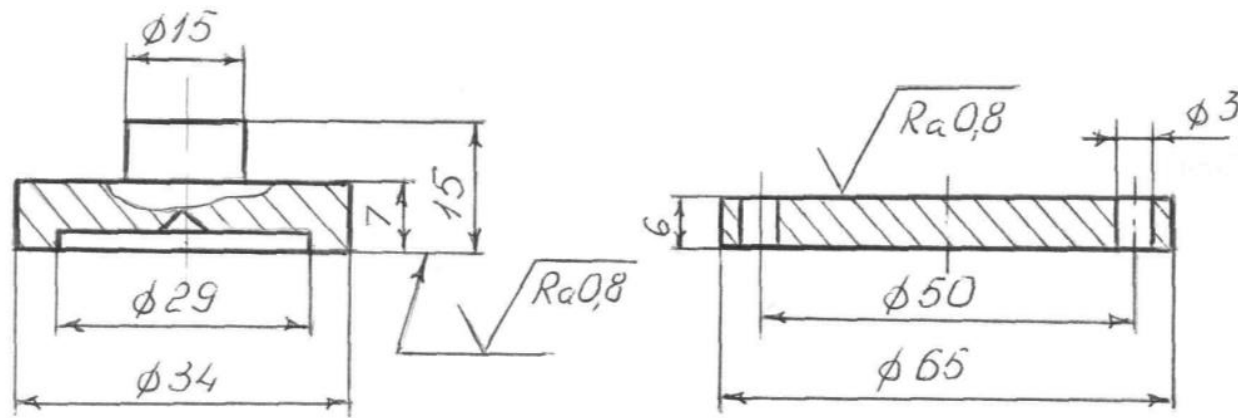

Fig. 3. Sketch of the sample and the contour

A second-order Hartley plan has been used to study the effect of the technological parameters of the carbohydration process on wear resistance. Research parameters for durability: medium - oil Industrial 20, sliding speed $V=1.24 \mathrm{~m} / \mathrm{s}$, specific load $p=4 \mathrm{MPa}$.

Methods of metallography, X-ray structural and chemical analyzes have been used in the study. As a result, the following characteristics of the carbohydrate layer have been determined: structure and thickness using MMP-2P, Neophot-21 microscopes; microhardness using PMT-3 microhardness meter; phase composition with the use of the DRON-3M X-ray device.

Mathematical methods of experiment planning (first- and second-order plans) and statistical methods of processing the results of experiments have been used to rationally conduct experiments and obtain reliable information.

\section{Results of the studies and their discussion}

In order to determine the optimum amount of propane in the saturation medium and pressure in the discharge chamber, a series of technological modes of hardening of 12XH3A steel have been carried out. Technological parameters of the process to form the carbide layer in the glow discharge: process temperature $T=580$ ${ }^{\circ} \mathrm{C}$, duration of hardening $\tau=240 \mathrm{~min}$, the pressure in the chamber varied from 67 PA to 333 PA, the content of propane in a saturated medium (in volume fraction) from $3 \%$ up to $15 \%$ (hereinafter referred to as a shortened composition of the gas mixture, for example, $15 \% \mathrm{C}_{3} \mathrm{H}_{8}$ ). $\mathrm{Ar}+\mathrm{C}_{3} \mathrm{H}_{8}$ gas mixture.

During the research of $12 \mathrm{XH} 3 \mathrm{~A}$ steel samples the dependences of the surface microhardness of the carbide layer on the technological parameters of the hardening process - the pressure in the discharge chamber and the cementitious gas content have been obtained. The data of the microhardness of the hardened steel are shown in Table 1. The dependences of the microhardness on the hardening parameters are shown in Fig. 4.

Table 1

\section{Results of studies of microhardness of steels 12XH3A,} strengthened in glow discharge in carbon medium

\begin{tabular}{|c|c|c|c|c|c|c|}
\hline \multirow[b]{2}{*}{ Mode number } & \multicolumn{4}{|c|}{ Technological parameters of the mode } & \multicolumn{2}{|c|}{ Microhardness of $\mathrm{H} 100, \mathrm{MPa}$} \\
\hline & $p, \mathrm{~Pa}(\mathrm{mmHg})$ & $\% \mathrm{C}_{3} \mathrm{H}_{8}$ & $I, \mathrm{~A}$ & $U, \mathrm{~V}$ & before strengthening & after hardening \\
\hline 1 & $333(2,5)$ & 9,0 & 6,8 & 315 & 2420 & 6500 \\
\hline 2 & $266(2,0)$ & 9,0 & 6,7 & 380 & 2700 & 7300 \\
\hline 3 & $200(1,5)$ & 9,0 & 5,6 & 410 & 2850 & 6800 \\
\hline 4 & $133(1,0)$ & 9,0 & 4,6 & 550 & 2450 & 5650 \\
\hline 5 & $67(0,5)$ & 9,0 & 3,6 & 970 & 2650 & 5000 \\
\hline 6 & $266(2,0)$ & 15,0 & 6,6 & 360 & 2600 & 5500 \\
\hline 7 & $266(2,0)$ & 12,0 & 6,5 & 400 & 2800 & 6700 \\
\hline 8 & $266(2,0)$ & 9,0 & 6,7 & 380 & 2750 & 7300 \\
\hline 9 & $266(2,0)$ & 6,0 & 6,1 & 450 & 2800 & 6250 \\
\hline 10 & $266(2,0)$ & 3,0 & 6,3 & 420 & 2700 & 5500 \\
\hline
\end{tabular}




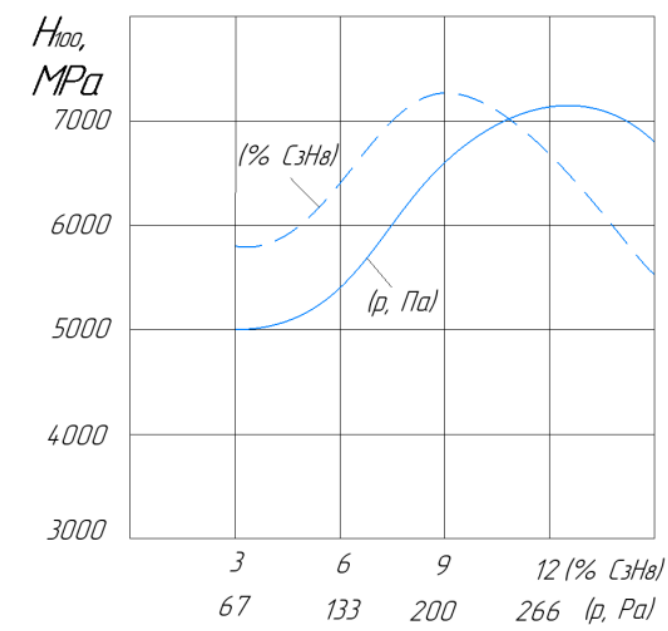

Fig. 4. Dependence of the microhardness of the carbide layer on the content of propane $\left(\%, \mathrm{C}_{3} \mathrm{H}_{8}\right)$ in a saturated medium and on the pressure in the discharge chamber $(p$, PA)

Previous studies of the effect of propane content in the medium and the pressure in the discharge chamber showed that for all the steels studied, there are optimal values of propane content in the saturation medium (from $8 \%$ to $11 \%$ ) and pressure in the discharge chamber (from 230 PA to 300 PA), at which surface microhardness will be maximum (Fig. 4) As the content of propane in the saturated medium increases, the surface of the samples is covered with soot, which impedes the penetration of the saturating gases into the metal surface and the formation of a hardened layer (Fig. 4).

In order to identify the effect of a variant of the carbohydration process on the physico-mechanical characteristics of $12 \mathrm{XH} 3 \mathrm{~A}$ steel, three variants of the process of hardening have been carried out:

1) carbon saturation $\left(\tau=120 \mathrm{~min}\right.$, medium $\left.88 \% \mathrm{Ar}+12 \% \mathrm{C}_{3} \mathrm{H}_{8}\right)+$ nitrogen saturation $(\tau=120 \mathrm{~min}$, medium $25 \% \mathrm{Ar}+75 \% \mathrm{~N}_{2}$ );

2) nitrogen saturation $\left(\tau=120 \mathrm{~min}\right.$, medium $\left.25 \% \mathrm{Ar}+75 \% \mathrm{~N}_{2}\right)+$ carbon saturation $(\tau=120 \mathrm{~min}$, medium $\left.88 \% \mathrm{Ar}+12 \% \mathrm{C}_{3} \mathrm{H}_{8}\right)$; $\left.12 \% \mathrm{C}_{3} \mathrm{H}_{8}\right)$.

3) joint saturation of the surface with nitrogen and carbon $\left(\tau=240\right.$ min, medium $-88 \%\left(\mathrm{Ar}+\mathrm{N}_{2}\right)+$

The process temperature and pressure in the discharge chamber in all three variants of the hardening process remained unchanged. The results of studies of surface microhardness, the thickness of the hardened layer and the thickness of the carbonitride zone of hardened steels are shown in Table 2. The microstructures of steels for various variants of technological hardening processes are shown in Fig. 5.

\section{Characteristics of the carbohydrated layer of steels strengthened in the glow discharge depending on the variant of the process}

Table 2

\begin{tabular}{|c|c|c|c|c|c|c|}
\hline \multirow[b]{2}{*}{$\begin{array}{l}\text { Mode } \\
\text { number }\end{array}$} & \multirow[b]{2}{*}{$\begin{array}{l}\text { Options } \\
\text { reinforcement mode }\end{array}$} & \multirow[b]{2}{*}{$\begin{array}{l}\text { Brand of } \\
\text { steel }\end{array}$} & \multicolumn{2}{|c|}{$\begin{array}{c}\text { Microhardness } \\
\mathrm{H} 100, \mathrm{MPa}\end{array}$} & \multirow{2}{*}{$\begin{array}{l}\text { The thickness } \\
\text { of the } \\
\text { hardened } \\
\text { layer, } \mu \mathrm{m}\end{array}$} & \multirow{2}{*}{$\begin{array}{l}\text { Thickness } \\
\text { carbonite } \\
\text { zone, } \mu \mathrm{m}\end{array}$} \\
\hline & & & $\begin{array}{l}\text { before } \\
\text { strengthen- } \\
\text { ing }\end{array}$ & $\begin{array}{c}\text { after } \\
\text { strengthenin } \\
\mathrm{g} \\
\end{array}$ & & \\
\hline 1 & $\begin{array}{c}\tau=120 \mathrm{~min}, \\
88 \% \mathrm{Ar}+12 \% \mathrm{C}_{3} \mathrm{H}_{8} \\
\tau=120 \mathrm{xB}, \\
25 \% \mathrm{Ar}+75 \% \mathrm{~N}_{2} \\
T=580{ }^{\circ} \mathrm{C}, p=266 \text { Па }\end{array}$ & $12 \mathrm{XH} 3 \mathrm{~A}$ & 2700 & 7800 & 48 & 20 \\
\hline 2 & $\begin{array}{c}\tau=120 \mathrm{xв} \\
25 \% \mathrm{Ar}+75 \% \mathrm{~N}_{2} \\
\tau=120 \mathrm{xB}, \\
88 \% \mathrm{Ar}+12 \% \mathrm{C}_{3} \mathrm{H}_{8} \\
T=580^{\circ} \mathrm{C}, p=266 \mathrm{\Pi a}\end{array}$ & $12 \mathrm{XH} 3 \mathrm{~A}$ & 2800 & 8200 & 100 & 15 \\
\hline 3 & $\begin{array}{c}\tau=240 \mathrm{xв}, \\
88 \%(\mathrm{Ar}+\mathrm{N} 2)+12 \% \mathrm{C}_{3} \mathrm{H}_{8} \\
T=580{ }^{\circ} \mathrm{C}, p=266 \Pi \mathrm{a}\end{array}$ & $12 \mathrm{XH} 3 \mathrm{~A}$ & 2750 & 11000 & 85 & 8 \\
\hline
\end{tabular}


As shown by the research, the variant of the technological process of hardening significantly affects the physical and mechanical characteristics of the strengthened layer. In all three variants of the process, the hardened layer consists of a surface carbonitrid zone and a diffusion zone of internal nitriding, but the properties of these zones in different variants of the process are different. Thus, with the first steel hardening $(\tau=120 \mathrm{~min}$, medium (88\% $\left.\mathrm{Ar}+12 \% \mathrm{C}_{3} \mathrm{H}_{8}\right) ; \tau=120 \mathrm{~min}$, medium $\left.\left(25 \% \mathrm{Ar}+75 \% \mathrm{~N}_{2}\right), T=580{ }^{\circ} \mathrm{C}, p=266 \mathrm{~Pa}\right)$ the thickness of the carbonitride zone is maximal and the internal nitriding zone has a small thickness. This is explained by the fact that the carbonitride layer created on the surface of the steel in the first stage of processing performs the function of shielding the surface from penetration into the surface layer of metal by nitrogen ions (Fig. 5, a).

When strengthened in the second mode $(\tau=120 \mathrm{~min}$, medium $(25 \% \mathrm{Ar}+75 \% \mathrm{~N} 2) ; \tau=120 \mathrm{~min}$, medium (88\% $\left.\left.\mathrm{Ar}+12 \% \mathrm{C}_{3} \mathrm{H}_{8}\right), T=580^{\circ} \mathrm{C}, p=266 \mathrm{PA}\right)$ both carbonitridine zone and zone of internal nitriding have the greatest thickness (Fig. 5, a, b), but with such strengthening in the diffusion zone carbonitrid inclusions are formed in the form of a grid, which significantly reduce the plasticity of the layer and at dynamic loads are the centers of origin of microcracks.

The most optimal variant of carboazotation in the glow discharge is the simultaneous saturation of the metal surface with nitrogen and carbon (Fig. 5, c). At the same time, a composite layer is formed on the surface of the steel, which consists of an external carbonitrid zone and a developed diffusion zone without separation along the grain boundaries $\varepsilon$ - phase, which increases the resistance to abrasive and adhesion wear, as well as corrosion fatigue. The thickness of the carbonitrid zone and the zone of internal nitriding, and as a consequence, the thickness of the entire hardened layer, while simultaneously saturating the surface layer with nitrogen and carbon, have a lower thickness than in stepwise strengthening, but are characterized by better physical and mechanical properties (surface hardness, surface hardness) the hardness of the layer thickness. Therefore, when carbohydrated in a smoldering discharge, the option of simultaneous saturation of the surface of steels with nitrogen and carbon is taken as the main one.

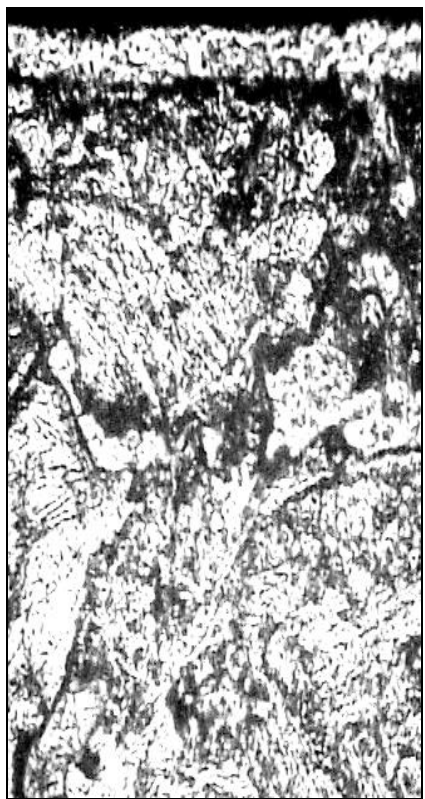

a

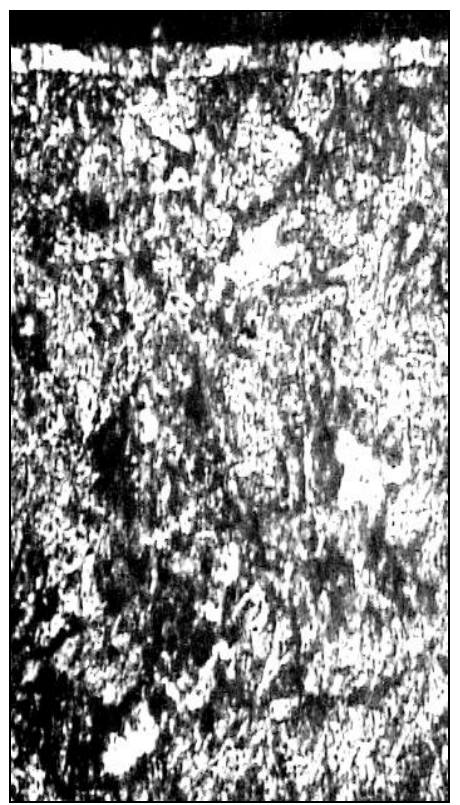

b

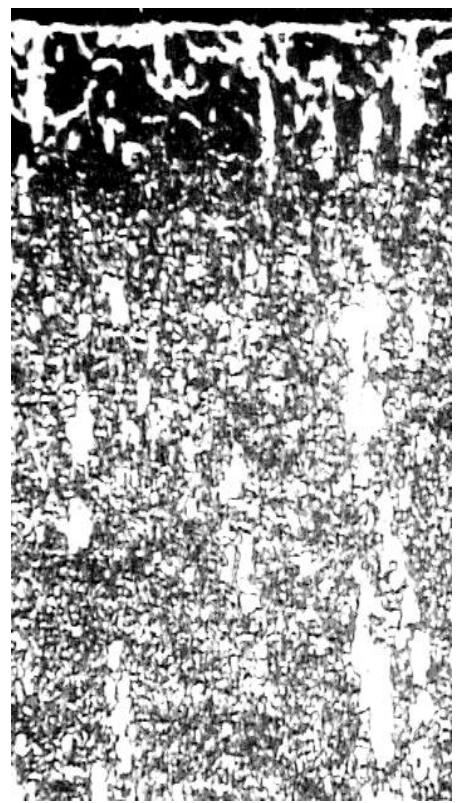

Fig. 5. Microstructure of 12XH3A steel, hardened BATR by different process options, $\times \mathbf{5 0 0}$

To study the effect of technological parameters of the carbon dioxide process in the smoldering discharge on the microhardness, thickness, structure and phase composition of the carbonitride layer and optimize the technological parameters of the process, an experiment planning method, in particular a second-order Hartley plan, has been applied. The test specimens were installed in a discharge chamber in special devices, the design of which allows, by slight replacement of some simple parts, to use them for simultaneous loading of several parts and samples, which differ in type and size. The results of the experimental studies of the microhardness and thickness of the carbohydrated layer of steel $12 \mathrm{HN} 3 \mathrm{~A}$ are shown in table 3 .

Fig. 6 shows a diagram of the change in the microhardness of H100 samples of 12HN3A steel in depth of the carbohydrate layer at different technological modes. From these diagrams it can be seen that when carbonitriding in a glow discharge, as a rule, the highest hardness is obtained on the surface of the workpiece. This is because a carbonitride $\varepsilon$ - phase is formed on the surface of the workpiece, which consists of carbonitrides of the type $\mathrm{Fe} 2(\mathrm{~N}, \mathrm{C}), \mathrm{Fe} 3(\mathrm{~N}, \mathrm{C}), \mathrm{Fe} 4(\mathrm{~N}, \mathrm{C})$. The carbonitride zone has high hardness, high corrosion resistance, in- 
creased wear resistance. The thickness of the carbonitride zone reaches a thickness of up to $25 \mu \mathrm{m}$. Below the carbonitrid zone is the zone of internal nitriding, which has a large thickness and is the main part of the carbohydrate layer. The internal nitriding zone consists of a nitrogenous solid solution of the parent metal, its nitrides and nitrides of alloying elements.

Table 3

\section{Modes of carbohydrogenation in glow discharge and metallographic analysis data of 12XH3A steel}

\begin{tabular}{|c|c|c|c|c|c|c|c|}
\hline \multirow[b]{2}{*}{$\begin{array}{l}\text { Mode } \\
\text { number }\end{array}$} & \multicolumn{4}{|c|}{$\begin{array}{l}\text { Technological parameters of the process of ionic } \\
\text { carbohydration }\end{array}$} & \multirow{2}{*}{$\begin{array}{c}\text { The thickness } \\
\text { of the } \\
\text { hardened } \\
\text { layer } h, \text { мкм }\end{array}$} & \multirow{2}{*}{$\begin{array}{l}\text { The thickness } \\
\text { of the carbo- } \\
\text { nitride zone, } \\
\text { мкм }\end{array}$} & \multirow{2}{*}{$\begin{array}{c}\text { Surface } \\
\text { micro- } \\
\text { hardness } \\
\text { H100, MPa }\end{array}$} \\
\hline & $\begin{array}{l}\text { temperature } \\
\qquad T,{ }^{\circ} \mathrm{C}\end{array}$ & $\begin{array}{c}\text { pressure } \\
p, \text { Па }\end{array}$ & $\begin{array}{l}\text { duration } \\
\tau, \mathrm{XB}\end{array}$ & $\begin{array}{c}\text { propane } \\
\text { content in the } \\
\text { environment, \% }\end{array}$ & & & \\
\hline 1 & 570 & 320 & 185 & 9 & 145 & 8 & 8680 \\
\hline 2 & 510 & 320 & 185 & 9 & 125 & 10 & 9910 \\
\hline 3 & 570 & 160 & 185 & 3 & 180 & 18 & 10850 \\
\hline 4 & 510 & 160 & 185 & 3 & 150 & 17 & 10040 \\
\hline 5 & 570 & 320 & 75 & 3 & 165 & 8 & 7750 \\
\hline 6 & 510 & 320 & 75 & 3 & 140 & 6 & 6800 \\
\hline 7 & 570 & 160 & 75 & 9 & 125 & 14 & 8680 \\
\hline 8 & 510 & 160 & 75 & 9 & 85 & 10 & 10830 \\
\hline 9 & 480 & 240 & 130 & 6 & 90 & 15 & 10500 \\
\hline 10 & 600 & 240 & 130 & 6 & 160 & 10 & 8100 \\
\hline 11 & 540 & 80 & 130 & 6 & 140 & 5 & 7650 \\
\hline 12 & 540 & 400 & 130 & 6 & 120 & 6 & 7580 \\
\hline 13 & 540 & 240 & 20 & 6 & 100 & 11 & 11000 \\
\hline 14 & 540 & 240 & 240 & 6 & 170 & 9 & 9890 \\
\hline 15 & 540 & 240 & 130 & 0 & 225 & 0 & 10190 \\
\hline 16 & 540 & 240 & 130 & 12 & 80 & 20 & 11540 \\
\hline 17 & 540 & 240 & 130 & 6 & 130 & 18 & 11540 \\
\hline 18 & 540 & 240 & 130 & 6 & 135 & 17 & 11500 \\
\hline 19 & 540 & 240 & 130 & 6 & 130 & 18 & 11580 \\
\hline 20 & 540 & 240 & 130 & 6 & 140 & 19 & 11560 \\
\hline
\end{tabular}

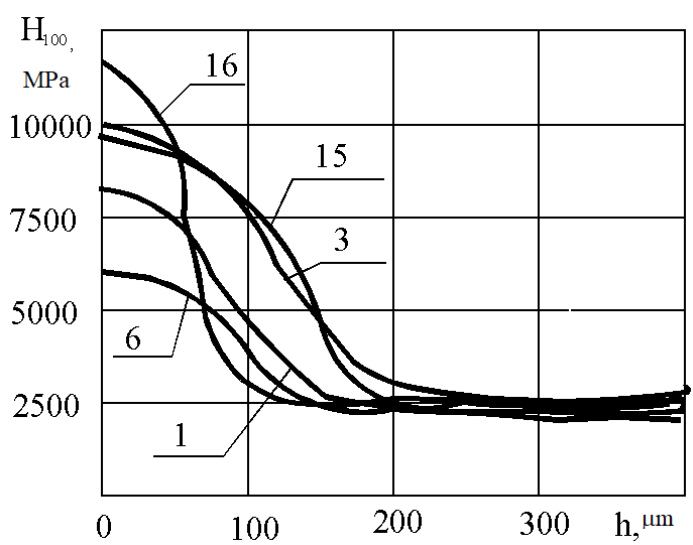

Fig. 6. Diagram of change of microhardness of 12XH3A steel in depth of carbohydrated layer at different technological modes

of hardening (figures on curves - numbers of modes in table 3 )

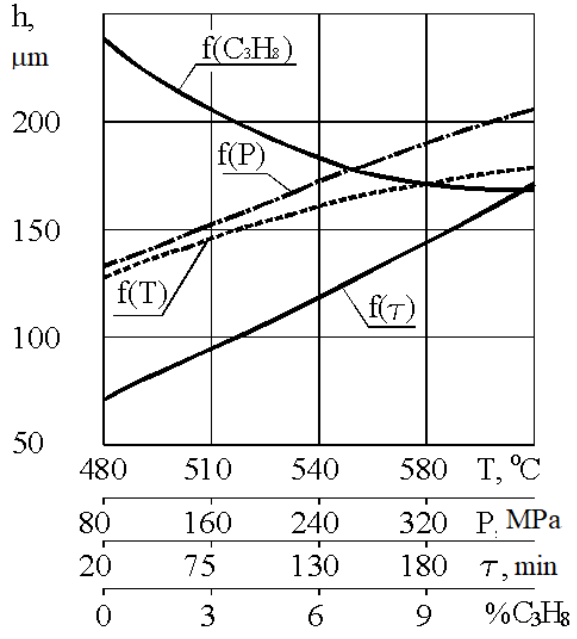

Fig. 7. Dependence of the thickness of the hardened layer of steel 12XH3A

on the technological parameters of carbohydration

in the glow discharge

Thus, carbohydrogenation in a glow discharge allows to change the structure of the hardened layer by changing the technological parameters of the saturation process, and as a consequence, to change its operational properties. 
The most intense increase in the thickness of the nitrided layer occurs in the initial period, especially during the first $20 \mathrm{~min}$, when there is an intense absorption of nitrogen and carbon by the surface zone, which has a large number of defects from ion bombardment during the period of ion purification.

In the future, the process of increasing the thickness of the layer is slowed down. Therefore, the greatest advantage of increasing the rate of formation of the diffusion layer with ionic carbohydration is achieved within the first 6 hours. As the duration of the ionic carbohydration increases, the thickness of the carbonitrid zone increases. However, the intensity of its growth is lower and has marginal values that depend on the ratio of other process parameters.

The results of studies of the wear resistance of specimens of 12XH3A steel strengthened by the glow discharge method of carbotizing in different modes using the Hartley 2nd order plan are shown in Table 4.

Table 4

The amount of wear of specimens from different steels at sliding friction, strengthened by carbon dioxide in glow discharge according to the Hartley plan

\begin{tabular}{|l|l|l|l|l|l|l|l|l|l|l|l|l|l|l|l|l|l|l|l|l|}
\hline $\begin{array}{l}\text { Mode } \\
\text { number }\end{array}$ & 1 & 2 & 3 & 4 & 5 & 6 & 7 & 8 & 9 & 10 & 11 & 12 & 13 & 14 & 15 & 16 & 17 & 18 & 19 & 20 \\
\hline $\begin{array}{l}\text { The } \\
\text { amount } \\
\text { of wear } \\
U, \mu \mathrm{m}\end{array}$ & 2 & 15 & 13 & 10 & 12,5 & 28 & 43 & 17 & 13 & 16 & 20 & 21 & 18 & 18,5 & 22 & 24 & 17 & 21,5 & 21 & 22 \\
\hline
\end{tabular}

The nature of the wear curves shows that in all the experiments there is a period of working (Fig. 8), which is characterized by a higher intensity of wear, and a period of normal operation with a slight intensity of wear. Comparison of wear values during the working-in period and during normal operation shows that the former significantly influences the process of wear of the friction pair, and as a consequence, the durability of the parts. Factors such as the structure of the surface layer, its chemical composition, surface roughness and operational parameters (specific load, velocity, environment) have a significant influence on the amount of wear during this period. By changing all these parameters, it is possible to achieve a significant reduction in the wear rate during the working period.

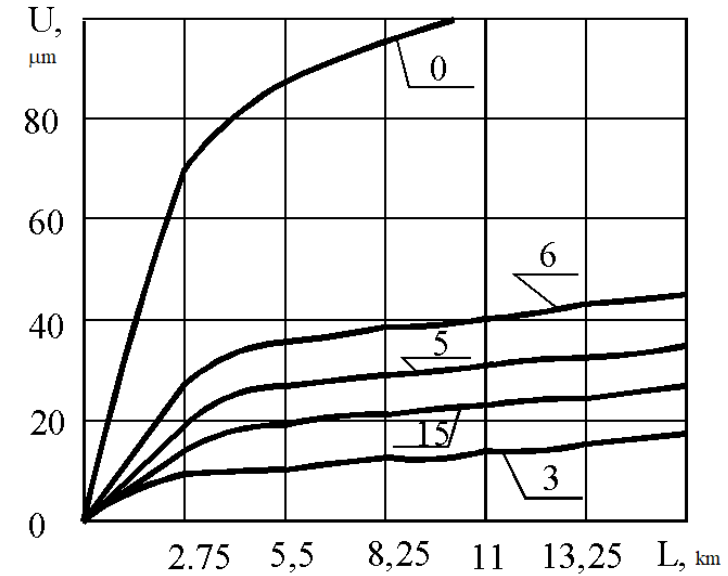

Fig. 8. Kinetics of wear of the samples from $12 \mathrm{XH3A}$ steel, strengthened by the carbooting method

(figures on curves - numbers of the modes of hardening in table 4)

Fig. 8 shows the dependence of the wear of the samples from 12XH3A steel, from the parameters of the process of carbohydration in glow discharge. The graphs show that the reinforcement mode has an ambiguous effect on the wear process both in magnitude and in character. Such dependencies show not only the degree of influence of one or another technological parameter on the tribological characterization of the surface of the hardened metal, but also allow to optimize the technological process of carbohydration according to this characteristic taking into account the real research conditions and material grade. So for the $12 \mathrm{XH} 3 \mathrm{~A}$ steel, the highest wear resistance in the conditions of the conducted studies has been recorded at carbonitriding in the glow discharge mode: $T=570{ }^{\circ} \mathrm{C}, p=160 \mathrm{PA}, \tau=185 \mathrm{~min}$, the amount of propane in a saturated medium $-9 \% \mathrm{C}_{3} \mathrm{H}_{8}$. Studies have shown that the wear resistance of carbohydrate samples in some modes is much higher than that of nitrided samples. Carbonitriding mode in glow discharge is of great influence on wear resistance, especially during the period of service. Thus, the wear value of hardened 12XH3A steel in mode 6 in the initial working period 
is 4 times larger than mode 3 . With the increase of the friction path, the wear value decreased and reached a constant value at the end of the working period. In this case, the difference in the wear rate of the samples hardened according to different modes decreased and almost did not differ during the normal wear. A similar pattern of wear of the carbohydrate samples was obtained for other steels.

This is explained by the fact that layers with different phase composition, hardness, plasticity and other physical and mechanical properties are formed on the surface of the specimens by hardening by the method of carbohydration in the glow discharge. With their optimal ratio for these conditions of wear we get the minimum intensity of wear of the friction pair both during the period of working out and during the period of normal wear. As the secondary structures (BC) that screen the friction surface are formed, the intensity of wear and tear decreases and, upon completion, becomes minimal, which is characteristic of the period of normal wear.

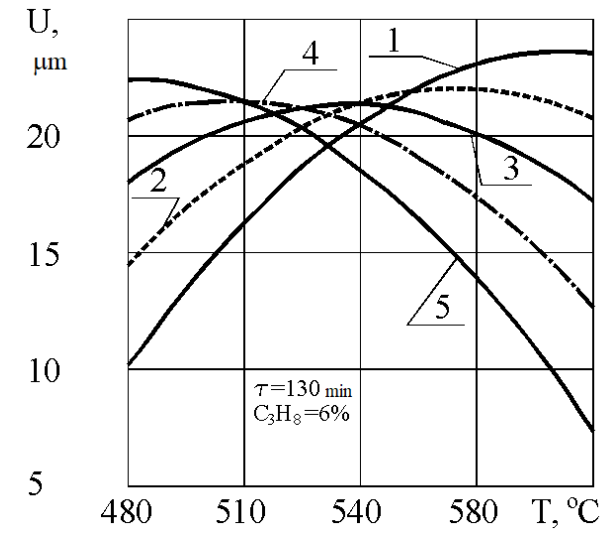

a

p: 1 - $80 \mathrm{MPa} ; 2$ - $160 \mathrm{MPa}$

3 - $240 \mathrm{MPa} ; 4$ - $320 \mathrm{MPa} ; 5$ - $400 \mathrm{MPa}$

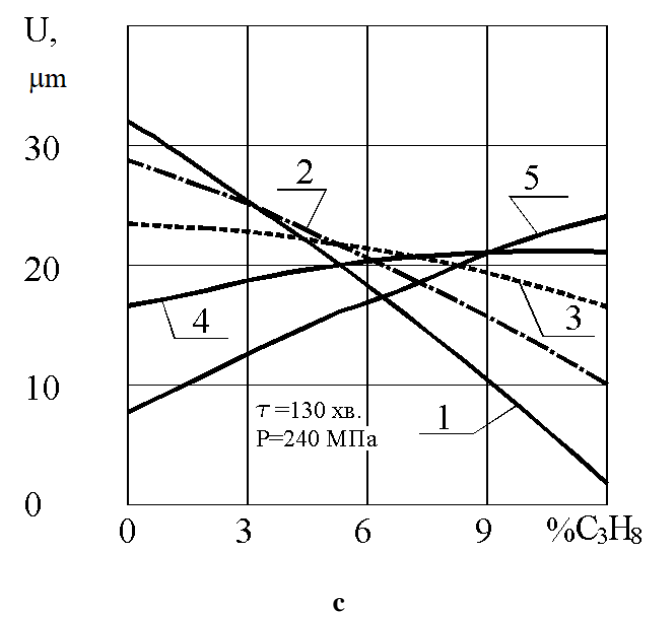

$T: 1-480{ }^{\circ} \mathrm{C} ; 2-510{ }^{\circ} \mathrm{C} ; 3-540{ }^{\circ} \mathrm{C}$; $4-570^{\circ} \mathrm{C} ; 5-600{ }^{\circ} \mathrm{C}$

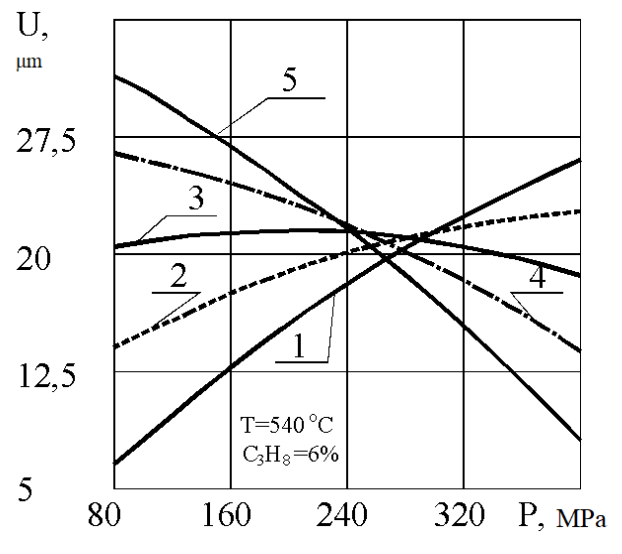

b

$\tau: 1$ - $20 \mathrm{~min} ; 2-75 \mathrm{~min} ; 3-130 \mathrm{~min}$; 4 - $185 \mathrm{~min} ; 5$ - $240 \mathrm{~min}$

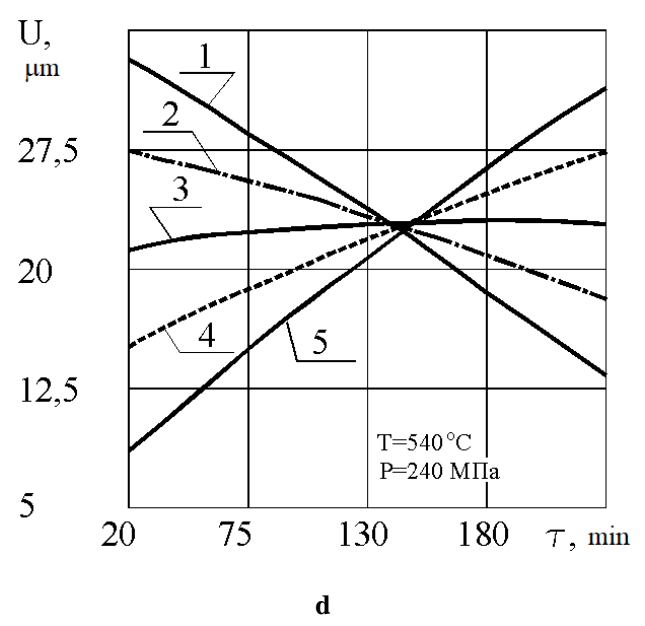

$\% \mathrm{C}_{3} \mathrm{H}_{8}: 1-0 \% ; 2-3 \% ; 3-6 \%$; $4-9 \% ; 5-12 \%$

Fig. 9. Influence of parameters of technological process of carbotation on wear resistance of $12 \mathrm{XH3A}$ steel

Secondary structures are a new phase that is spontaneously formed by friction as a result of the interaction of the surface layers of solids, lubricants and the gas environment. Secondary structures are characterized by friction and strength properties that normalize friction and wear. Thin films of secondary structures differ from starting materials in composition, structure, properties. Sun formation is a thermodynamic act of passivation of friction-activated solids.

The secondary structures formed during the friction process protect the starting material from mechanical and physical and chemical destruction. External mechanical factors acting on the friction surface lead to the destruction of the shielding phase, but at the same time, these factors and the associated processes of transfer of the substance from the environment ensure its regeneration. In the normal friction range, the processes of formation and destruction of aircraft films are in dynamic equilibrium and are automatically regulated.

Secondary structures are of two main types and have a large range of intermediate states: Type I - solid oxidizing solutions in materials; Type II - chemical compounds of materials with non-stoichiometric oxidants. 
For both types of aircraft common are their surface localization, dislocation structure, ability to minimize friction and wear and eliminate unacceptable grasping processes, fatigue. But at the same time there are considerable differences between the types of secondary structures:

- while the Sun Type I have the properties of excessive plasticity, the structures of Type II are characterized by less plasticity, increased fragility and greater strength;

- on the submicrometer of the friction surface, the coverings of the sun of the first and second types differ sharply: the friction surfaces covered by the sun films of the first type are geometrically homogeneous and the surfaces covered by the films of the second type are heterogeneous;

- adsorption characteristics differ sharply: the surfaces that are covered with Type I have a low wetting of lubricants, and the surface of Type II is increased.

Changing the mode of the carbohydration process, it is possible to form an optimal micro relief on the friction surface, which corresponds to the state of the surface layers in the process of formation of secondary structures Types I and II, the totality of which in these operating conditions has a significant impact on the fastest formation of secondary structures and minimal wear of the friction surfaces as in working-in period and during normal wear and tear.

Fig. 10 presents the results of complex studies of the influence of the main technological factors on the durability of 12XH3A steel, using the design of experiments (Hartley plan, Table 4), which allow to determine the optimal technological modes of carbohydration in the smoldering discharge to ensure the maximum durability of the studied steels. These modes are: for $12 \mathrm{XH} 3 \mathrm{~A}$ steel: temperature of carboxygenation $-540{ }^{\circ} \mathrm{C}$, pressure - $400 \mathrm{~Pa}$, duration of saturation - $240 \mathrm{~min}$, content of propane - $12 \%$.

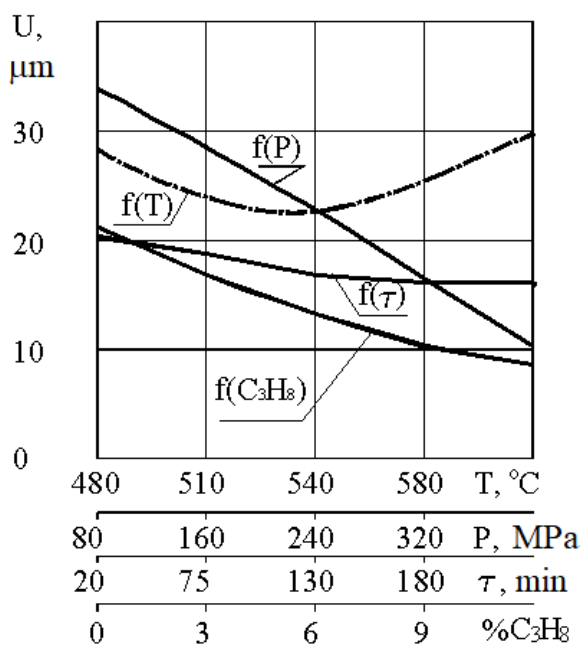

Fig. 10. Dependence of wear of $12 \mathrm{XH3A}$ steel

on the technological parameters

of carbohydration in glow discharge

The analysis of the obtained dependences shows that the increased hardness of the material does not always have a positive effect on its durability. The values of the technological parameters of the hardening process, which provide the maximum microhardness of the surface and the thickness of the hardened layer do not always coincide with the values of the technological parameters of the process according to the criterion of maximum wear resistance. The amount of wear of the friction surfaces depends not only on the process parameters but also on the operating conditions (friction surface pressure, sliding speed and environment). Therefore, in order to improve the wear resistance of friction pairs for different materials and modes of carbohydration in the glow discharge, it is necessary to find the optimal values of the process parameters depending on the friction operating conditions.

\section{Conclusions}

Plasma discharge carbohydration technology has been developed in anhydrous media, one of the advantages of which is the controllability of technological parameters of the process in order to achieve the optimum physical and mechanical properties of the strengthened materials and, as a consequence, to increase their operational characteristics.

A technique for studying the influence of technological parameters of the carbohydration process on the properties of structural materials has been developed, which allows to find the optimal modes of hardening depending on the operating conditions.

The durability studies of specimens of $12 \mathrm{XH} 3 \mathrm{~A}$ steel strengthened by the method of carboazotation in the smoldering discharge using mathematical methods of experiment planning have been carried out. The pa- 
rameters of the technological process of hardening (temperature, pressure, composition of the saturation medium, the duration of the process) affect the wear resistance over a wide range and allow you to optimize the process by the criterion of maximum wear resistance.

\section{References}

1. Lahtin Yu.M., Kogan Ya.D., Shaposhnikov V.N. Reguliruemye processy azotirovaniya v tleyushem razryade. V kn. Progressivnye metody himiko-termicheskoj obrabotki. M. Mashinostroenie, 1979. $184 \mathrm{s.}$

2. Arzamasov B.N., Bratuhin A.G., Eliseev Yu.S., Panajoti T.A. Ionnaya himiko-termicheskaya obrabotka splavov. M. Izd-vo MGTU im. N.E.Baumana, 1999. $400 \mathrm{~s}$.

3. Polyak M.S. Tehnologiya uprochneniya. M. Mashinostroenie, 1995. $832 \mathrm{s.}$

4. Stechishina N.M, Lyuhovec V.V., Stechishin M.S. Vpliv tehnologichnih parametriv karboazotuvannya na znosostijkist stali 45. Problemi tertya ta znoshuvannya. K.: NAU, 2019, №3(84). S.76-82.

5. Stechishin M.S., Luk'yanyuk M.M., Luk'yanyuk M.V. Modelyuvannya tribosistemi pri bezvodnevomu azotuvanni v tliyuchomu rozryadi. K. NAU, 2019, 2019, №3(84). S. 97-10.

Скиба М.Є., Стечишин М.С., Лук'янюк М.В., Мартинюк А.В., Цепенюк М.І. Зносостійкість та фізико-хімічні властивості карбоазотованої сталі 12ХН3А.

У роботі приведено результати дослідження впливу безводневого карбоазотування в тліючому розряді на мікротвердість зміцненого шару сталі $12 \mathrm{XH3А} \mathrm{залежно} \mathrm{від} \mathrm{вмісту} \mathrm{пропану} \mathrm{та} \mathrm{тиску} \mathrm{газового}$ середовища. Відповідно до розробленої методики дослідження впливу технологічних параметрів процесу карбоазотування на властивості конструкційних матеріалів, знайдено оптимальні режими зміцнення сталі 12ХНЗА залежно від умов експлуатації.

Ключові слова: карбоазотування, мікротвердість, структура. 